\title{
蛾はコウモリの超音波を嫌がる 超音波を利用した防蛾技術の開発
}

環境や生物多様性の保全は，持続可能な社会を構築す るための世界的な最重要課題の一つである．わが国の農 業の場面においても，有機栽培や減農薬栽培などへの関 心は高まりつつあり，実際に取り組みが進められている ところである。また，これまでの農業は化学合成殺虫剤 などのいわゆる農薬に依存してきた面が強いが，同一有 効成分を含む農薬の高頻度の使用に起因して農業害虫に おける殺虫剤抵抗性の発達が顕在化してきた。さらに, 日本の農産物の積極的な輸出が図られている昨今, 日本 よりも一般に低く設定された輸出相手国の残留農薬基準 に適合させるためにも，化学合成殺虫剤に代わる病害虫 防除技術の開発が必須となっている.

農作物を加害する蛾の仲間は基本的に夜間に飛び回る が，これらはコウモリにとって格好のエサとなる．食虫 コウモリは一般に超音波（周波数が 20 キロヘルッ（1秒 あたりの振動回数が 2 万回）以上のヒトには聞こえない 音）を発し，餌となる虫から跳ね返るエコーを手掛かり に虫の位置を高精度に捉え, 捕食を成功させる(1).これ に対抗するために大部分の蛾は鼓膜器官からなる耳を進 化させ，コウモリに食べられないよう，超音波を聞くと 逃げ出したり飛ぶのを止めたりする ${ }^{(1,2)}$. このような蛾 の超音波に対する忌避行動を利用すれば，超音波を人工 的に出力することにより, 農作物を蛾の被害から守れる ものと期待される．微小な蛾を除く約 11 万 5,000 種の蛾 のうち，85\%の種が耳をもっており，たとえばハスモン ヨトウ，才オタバコガ，イネヨトウ，マイマイガなどの ヨトウガ類, トモエガ類, シャクガ類, メイガ類, ツト
ガ類など農業害虫となっている多くの蛾が合成超音波を 用いた防除の対象となりうる(1,3).耳をもつ蛾がコウモ リの発する超音波パルスを忌避することは古くから知ら れており，少なくとも1962年には農業上の応用が試み られている(3). しかしながら，どのような超音波パルス を蛾が最も嫌がるかといった精査はほとんどされておら ず，実用化には至っていない。特に蛾のメスが卵を産み に農作物へ飛来する行動を, 複数の超音波パルスを用い て阻害する観察例はなく，合成超音波を利用した防除技 術の開発は停滞しているのが現状であった。そこでわれ われは，コウモリが発する超音波をヒントに作出した人 工の超音波を利用し，農業害虫である蛾の農作物への飛 来を効率的に阻害する手法の開発に取り組んでいる.

モモノゴマダラノメイガのメス成虫はモモやリンゴ, クリの果害に産卵し, 孵化した幼虫が果実を食害する. したがって，メス成虫の果実への飛来を妨げることに よって，幼虫による被害を未然に防ぐことができる．蛾 を食べるコウモリは，発する超音波パルスの長短に基づ いて 2 種類に大別される(1)。そこで，それぞれに対応す る「短い超音波パルス（モモジロコウモリ類の超音波を 模倣した長さ 5 ミリ秒と無音区間 11 ミリ秒を組合せた超 音波パルス)」と「長い超音波パルス（キクガシラコウ モリ類の超音波を模倣した長さ 30 ミリ秒と無音区間 30 ミリ秒を組合せた超音波パルス)」をソフトウェア上で 合成し，蛾に聞かせた（図1)。ここでは，いずれの超 音波も，モモノゴマダラノメイガの聴覚感受性が高い周 波数の 50 キロヘルッのみで構成されたパルスを用いた。
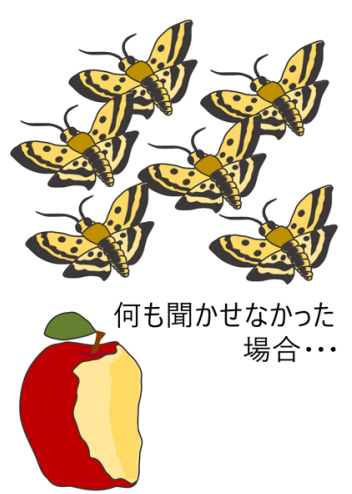

飛来率は64\%

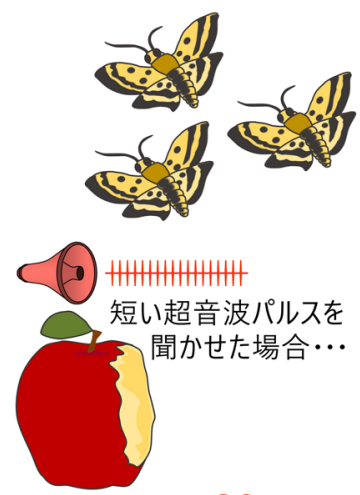

飛来率は28\%に減少

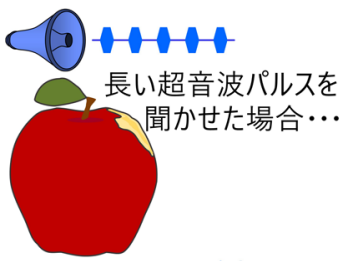

飛来率は10\%に激減
図1—モモノゴマダラノメイガのメスが嫌 う超音波パルス

キクガシラコウモリ類の発する超音波パルス の時間構造（パルスと無音区間の長さ）を模 して合成した“長い超音波パルス”は，モモ ノゴマダラノメイガのメスが卵を産みにリン ゴ果実へ飛来する行動を高効率で阻害する。 
モモノゴマダラノメイガを対象にした試験では, 風洞装 置内で，風上に置いたリンゴの幼果に 15 分間に飛来し たメス成虫の割合（飛来率）を比較した（図1)。超音 波パルスを提示しない条件における飛来率は64\%で あったのに対し，短い超音波パルスを聞かせた場合には $28 \%$ ，長い超音波パルスの場合には10\%に飛来率が低 下した（図1）。超音波を聞かせなかった場合と比べ, 長い超音波パルスを聞かせた場合は飛来率が $1 / 6$ 以下に 抑制されており，超音波による蛾への高い忌避効果が確 認された ${ }^{(4)}$.

超音波を忌避する行動は多くの蛾で見られるため, 上 述のほかの蛾類害虫への適用拡大が期待される，その一 方で, 種内でのコミュニケーションに超音波を利用する 蛾も多数あることから，防除に適切な超音波パルスの長 さなどの検討には注意を要する(2,5)。また，超音波は大 気中で遠くまで伝わりにくいため, 果樹園のような開放 空間では十分な効果を得るために多数の超音波発生装置 の設置が必要となる。そのため, 経済的に導入すること はそれでは困難と考えられる。そこで, 蛾類害虫の侵入 経路が限定されるビニールハウスなど，超音波発生装置

\section{今日の話題}

\footnotetext{
の設置台数が少数でも農作物への飛来を抑制可能な生産 環境での利用を検証している。具体的には，施設栽培に おけるイチゴやトマトの主要害虫であるハスモンヨト ウ, さらには加工食品などで混入事例が報告されている 貯穀害虫のノシメマダラメイガなどを対象として, 忌避 効果の高いパルスと無音区間の長さを探索している。ま た，蛾の種類によって聞こえやすい周波数が異なること から，これらも含めた最適化を進めている. 現在, 本手 法に適した超音波発生装置の開発を産学官連携で進めて おり, 数年以内に製品化する予定である.

本研究は内閣府戦略的イノベーション創造プログラム (SIP)「次世代農林水産業創造技術」, 日本学術振興会 科学研究費（若手B 23780053）の支援により実施され た。

1) H. M. ter Hofstede \& J. M. Ratcliffe: J. Exp. Biol., 219, 1589 (2016).

2) R. Nakano, T. Takanashi \& A. Surlykke: J. Comp. Physiol. A Neuroethol. Sens. Neural Behav. Physiol., 201, 111 (2015).

3) 中野 亮: 植物防疫, 66, 300 (2012).

4) R. Nakano, F. Ihara, K. Mishiro, M. Toyama \& S. Toda: J. Insect Physiol., 83, 15 (2015).

5) R. Nakano, F. Ihara, K. Mishiro, M. Toyama \& S. Toda: Proc. Biol. Sci., 281, 20140840 (2014).

(中野 亮, 農業・食品産業技術総合研究機構果樹茶業 研究部門)

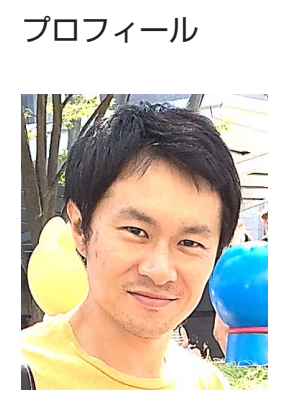

中 野 亮 (Ryo NAKANO)

$<$ 略歴>2003年明治大学農学部農学科卒 業 / 2008 年東京大学大学院農学生命科学 研究科生産・環境生物学専攻博士課程修 了 $/$ 同年日本学術振興会特別研究員 (東京 大学) $/ 2009$ 年理化学研究所脳科学総合研 究センター研究員 / 2010 年農業・食品産 業技術総合研究機構任期付研究員 $/ 2013$ 年同主任研究員 $/ 2014$ 年日本学術振興会 海外特別研究員 (トロント大学), 現在 (農研機構主任研究員) に至る<研究テー マと抱負 $>$ 昆虫の配偶行動, 音響交信, 捕 食者認知・回避行動, 超音波を用いた害虫 防除技術の開発<趣味 $>$ 散歩, 温泉, 料 理, 旅行, キャンプ

Copyright (C) 2017 公益社団法人日本農芸化学会 DOI: 10.1271/kagakutoseibutsu.55.452 